\title{
EFFECTS OF EDAPHIC AND PHYSIOGNOMIC FACTORS ON SPECIES DIVERSITY, DISTRIBUTION AND COMPOSITION IN RESERVED FOREST OF SATHAN GALI (MANSEHRA), PAKISTAN
}

\author{
KHAN, K. R. ${ }^{1,2^{*}}-$ ISHTIAQ, M. ${ }^{3 *}-$ IQBAL, Z. ${ }^{1}-$ ALAM, J. ${ }^{1}-$ BHATTI, K. H. ${ }^{4}-$ SHAH, A. H. ${ }^{2}-$ \\ FAROoQ, M. $^{2}-$ Ali, N. ${ }^{1}-$ MushtaQ, W. ${ }^{3}$ - MehmoOd, A. ${ }^{1}-$ MajID, A. ${ }^{1}$ \\ ${ }^{1}$ Department of Botany, Hazara University, Mansehra-21300, Pakistan \\ ${ }^{2}$ Department of Botany, Government Post-Graduate College, Mansehra-21300, Pakistan \\ ${ }^{3}$ Department of Botany, (Bhimber Campus), Mirpur University of Science \& Technology \\ (MUST), Mirpur-10250 (AJK), Pakistan \\ ${ }^{4}$ Department of Botany, University of Gujrat, Gujrat, Pakistan \\ *Corresponding authors \\ e-mail:drishtiaqajk@gmail.com; khalid_botnist@yahoo.com \\ (Received $13^{\text {th }}$ Sep 2017; accepted $11^{\text {th }}$ Jan 2018)
}

\begin{abstract}
Forests have pivotal role in life sustenance of indigenous people of the area and economy of any country at mass level. Forest health, diversity and richness depends various environmental parameters. In this study, impact of edaphic and physiographic factors on plant communities of reserved forest of Sathan Gali (Mansehra), Pakistan is analyzed. Quantitative and qualitative characteristics of plant species were studied dividing the area into 13 stands on physiognomic features. In this analysis 136 plant species of 58 families were classified into four prominent plant communities through TWINSPAN approach. The family index depicted that Asteraceae was dominant among 58 families. Biological spectrum (BS) expressed Therophytes as the dominant plants with $27.34 \%$ species, while leaf size spectrum (LSS) classification showed Mesophytes having 25.83\% species contribution. Importance value index (IVI) analysis proved that Pinus wallichiana had highest value (351.69) followed by Fragaria nubicola (62.88). In analysis, maximum species diversity (MSD) was found in Pinus-Pteris-Sarcococca community (0.102) while species richness (SR) was in Pinus-Digitaria-Sarcococca community (1.87) whereas maximum species maturity (MSM) was found in Pinus-Cedrus-Vibernum community (65.74). In two statistical analyses; it was found that DCA ordination of reserved forest indicated that the maximum gradient length was 3.32 for axis 1 and 2.57 for axis II while CCA ordination revealed that the maximum eigenvalue was 0.49 for axis 1 and 0.40 for axis II. Among environmental variables the maximum positive strength and impact on composition of community was recorded for altitude and phosphorous $(\mathrm{P})$ while maximum negative strength was recorded for barometric pressure and temperature.
\end{abstract}

Keywords: therophytes, biological spectrum, mesophytes, species richness, DCA

\section{Introduction}

Plants are very integral part of biosphere and ecosystem for life sustenance on the earth. Plants have diverse occurrence on earth and among these rich areas of diverse types of plants is named as forest. The forests are rich source of plant biodiversity of any country. Without healthy forests economy and environment of any country cannot be sustainable. Furthermore, forests are playing major role in provision of all necessities of life for many communities around the globe. Forests health and pattern of richness depends on many biotic and abiotic factors and later one have silent role on it. Phytosociology is the study of characteristics, classifications, relationships, and 
distribution of plant communities in forest or other plant rich zones (Mueller-Dombois and Ellenberg, 1974). The historical background of phytosociology can be traced back to Swiss botanist Josias Braun Blanquet (1884-1980) who is considered the founder of the phytosociology. In the $20^{\text {th }}$ century great efforts were made in the field of ecology and phytosociology. Braun Blanquet defined the plant association as a stable plant group in equilibrium with the surrounding environment characterized by certain dominant species illuminating a particular ecology. These leading species represent the major trends in the local vegetation allowing the ecologists to identify, distinguish and discuss dynamics of the community (Leveque, 2001). In the last few decades' scope of phytosociology became wider and investigates number of quantitative, qualitative and synthetic characteristics of plant communities e.g. density, dominance, abundance, floristic composition, vegetation structure, physiognomy, development and exchange multilateral relations of plants to one another and to the environmental variables and the classification of communities (Rieley and Page, 1990).

The existence of distinct forest types is exploratory of diversity in climatic and edaphic factors. Vegetation is the mainly physical representation of the environment (Kent, 2012). Any type of changes in habitats are first observed in the vegetation and forests are indicators of it. Vegetation is the result of the habitat, environmental conditions and existing biodiversity. Such study provides information about recognition and definition of different vegetation types and plant communities, identifying relationship between plant species distribution and environmental control. It also provides basis for prediction of possible future climatic changes (Kent and Coker, 1994) and on basis of which we may plan recommendations and practical steps to cope hazardous changes in environment.

Ecological diversity is considered to be a measure of the health of an ecosystem (McGardy-Steed and Morin, 2000). Variation in species diversity along environmental gradient is a major topic of ecological investigation in latest years (Currie and Francis, 2004). Monitoring of vegetation is an easy way for understanding the climatic conditions of an area (Niemi and Donald, 2004). With climate change, phytosociological studies will become more important because in most cases, only vegetation data is available to use for making comparisons. Phytosociological studies visualize the existing vegetation structure, species diversity, soil plant relationship and generate data on seasonal and temporal variations in available nutrients (MuellerDombois and Ellenberg, 1974). Plant communities as concrete definable units of vegetation that can be recognized and are apparent to the eye. Plant communities are often named after species that contribute to their unique structure or composition. The altitude, latitude, slope angle, aspect and humidity play an important role in formation and composition of plant community (Currie and Francis, 2004; Shaheen et al., 2012).

Species diversity is measured mathematically by indices and provides information about species richness, consistency and community composition as well as rarity or commonness of a species (Whittaker, 1977). Maturity index indicates about the ongoing climax trend as well as successional variations in a given community under the impact of ecological conditions and through this index we can find out the best suitable and favorable altitudinal zones for the plants (Rodolfo and Sermolli, 1948). Modern software packages have made the phytosociological studies more meaningful and predictable. A growing number of studies have used software packages. Peer et al. (2007) applied TWINSPAN and recognized 11 plant communities in Hindu Kush Mountains. Hussain et al. (2008) conducted study on species composition and 
community structure of 23 forest stands in Kumaon Himalaya. Out of which, they reported 19 tree communities and 17 ground vegetation communities. The distribution of tree species on DCA axis 1 showed influence of altitudinal gradient while the second axis of DCA indicated canopy cover and shrub diversity. Haq et al. (2015) and Mehmood et al. (2015) also evaluated similar approaches for the recognition plant communities.

The present study was designed with the objectives to investigate and correlate the vegetation of an unexplored Sathan Gali (Study area) with edaphic and physiographic factors and to classify the vegetation structure into plant communities with its ecological characteristics. It will be helpful for the conservation and sustainable utilization of plant resources of the area and also for further ecological investigations.

\section{Materials and methods}

\section{Study area}

Sathan Gali lies in District Mansehra of Khyber Pakhtoonkhawa (KPK), Pakistan. The study area is situated from 34.36132 to 34.36650 North latitudes and 073. 11067 to 073. 12488 East longitudes. Mansehra District of KPK consists of three tehsils; Mansehra, Oghi, and Balakot. Mansehra makes its boundary on the North to Kohistan and Battagram Districts, on the East surrounding by Muzaffarabad district of Azad Jammu and Kashmir, on the South to Abbottabad and Haripur districts and on the West to Shangla and Buner Districts (Fiaz, 2012) as these areas are shown in Figures 1 and 2.

\section{Climate of area}

The area receives heavy rain fall in Winter and Monsoon. The temperature of the area remains pleasant throughout the year except May and June. Snow often occurs in these forests particularly near its upper limits during the months of December to February. This heavy snow causes physical damage to the vegetation. As trees are over laden with snow and when wind blow most of the trees break. In May and June, the temperature is high as compared to rest of the months (Khan et al., 2016).

\section{Edaphology}

The rocks are gneiss, gneissose, schists, granitoid gneisses, mica schist and shales. Soil possesses higher moisture retaining capacity under the vegetation cover and acidic in nature. As agriculture land is inadequate and the peoples thus try to bring every available bit of land under cultivation in order to fight against the hunger. Terraces on hills slopes are constructed for cropping but they are not effective and durable. The soils from such slopes get washed away within two to three years and barren bed rocks left behind (Saddozai, 1996).

\section{Soil analysis}

Soil samples, down to a depth of $30 \mathrm{~cm}$, were collected from each stand. These soil sample were analyzed for percentage of sand, silt and clay), total organic matter (OM. $\%), \mathrm{pH}$, electrical conductivity in the Baffa laboratory (Allen et al., 1986). 


$$
\text { - } 1088 \text { - }
$$

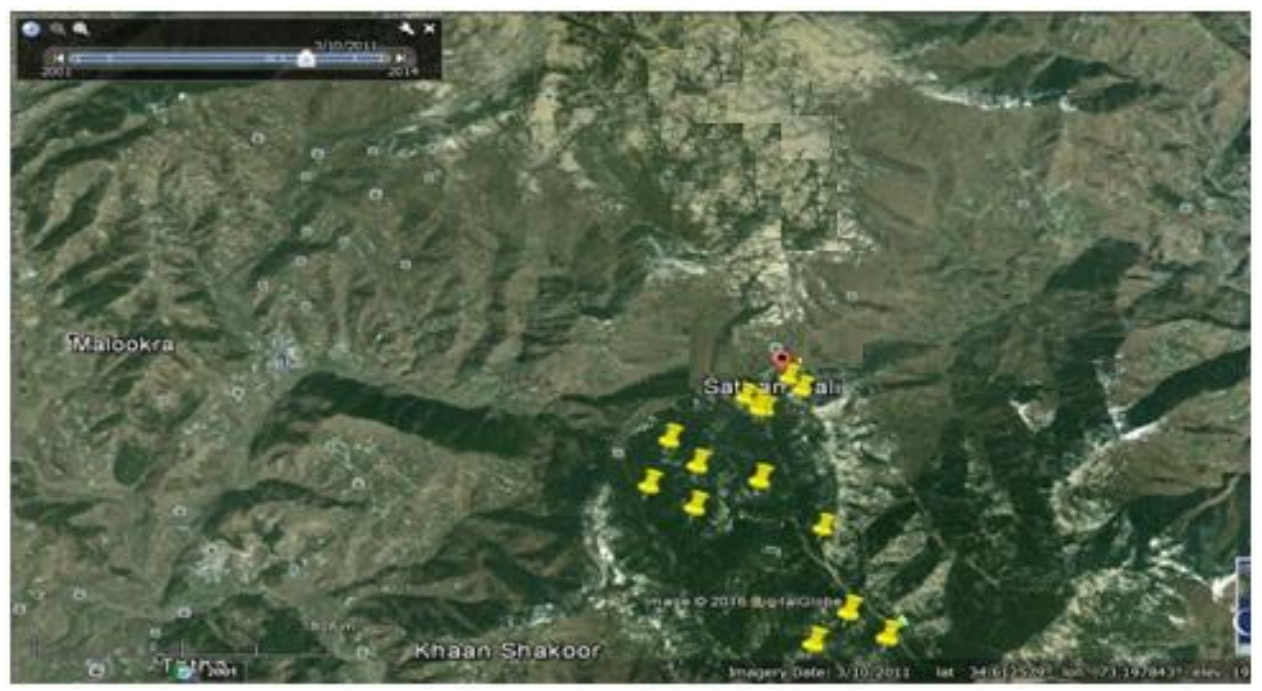

Figure 1. Map of the study area highlighting the stands selected for study in reserved forest

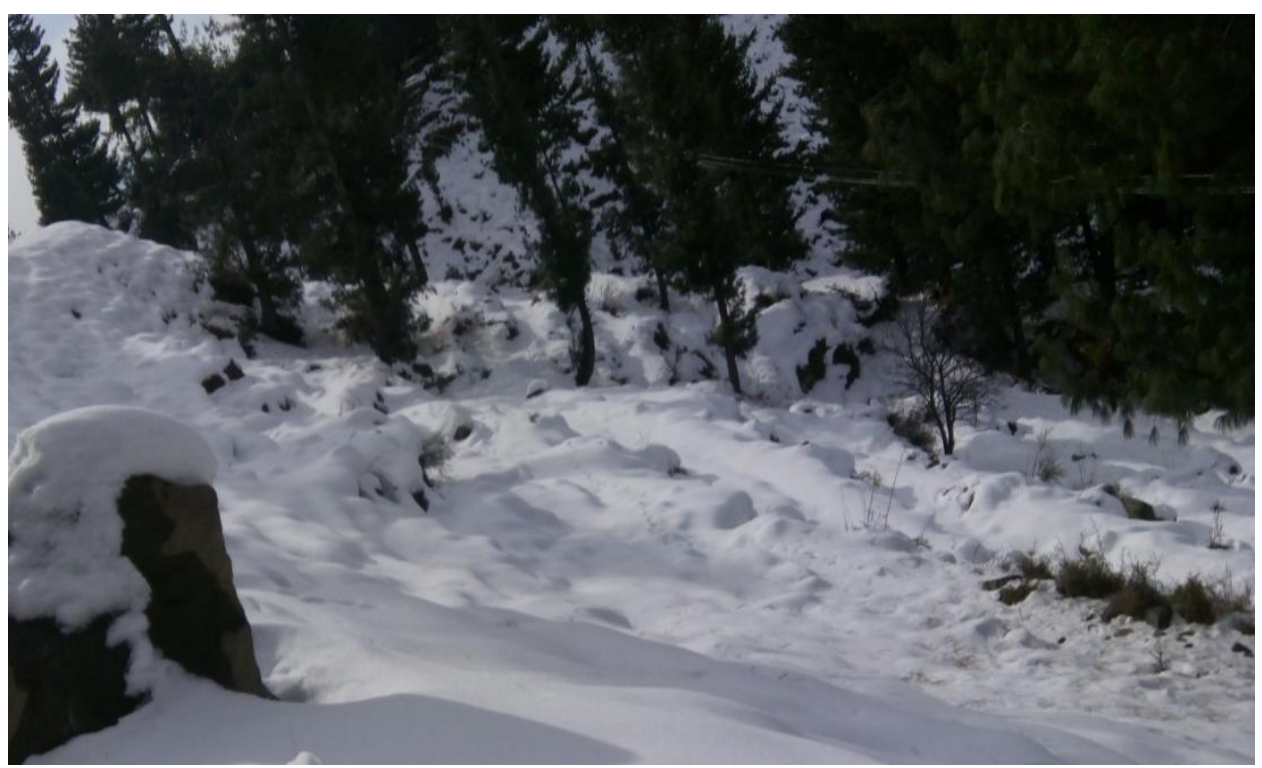

Figure 2. Scenic view of reserved forest

\section{Field studies}

The detailed field surveys have been carried out to study the phytosociological attributes of Sathan Gali (Reserved forest), Mansehra, Pakistan at regular intervals of different seasons, during 2013-2015. The whole area was divided into 13 stands on the basis of physiognomy of vegetation. Quadrate method was used for sampling the vegetation. The size of quadrate was $10 \times 2 \mathrm{~m}^{2}$ for trees $5 \times 2 \mathrm{~m}^{2}$ for shrubs and $1 \times 1 \mathrm{~m}^{2}$ for herbs, respectively (Malik, 1986). The number of quadrates for trees, shrubs and herbs were 5, 10 and 20 respectively. Both systematic and random quadrants that give better results were used. The distance between two adjacent stands was approximately $100 \mathrm{~m}$. The phytosociological attributes density, relative density, frequency, relative frequency, canopy cover, relative canopy cover, species diversity, species richness, 
species maturity and importance values index (IVI) were calculated. Trees with less than $1.5 \mathrm{~m}$ were considered as shrub. Coverage of shrubs and herbs was calculated after coverage classes Daubenmire (1959). Collected plant specimens of each species were dried, poisoned and mounted on standard herbarium sheets. The collected specimens were identified with the help of Flora of Pakistan (Nasir and Ali, 1971-1994; Ali and Qaisar, 1995-2004) and voucher specimens were deposited in the Herbarium of Hazara University Mansehra, KPK, Pakistan (HUP).

\section{Data analysis}

TWINSPAN was used for the classification of species and samples at the same time which is based on dividing reciprocal averaging ordination space. Detrended Correspondence Analysis (DCA) analysis was done to evaluate similarities/differences between the species and samples. A Canonical Correspondence Analysis (CAA) is an ordination to determine and analyze the correlation between species and environmental variables. The life form classes and leaf spectra of all plant species were determined and classified following after Raunkiaer (1934) and Mueller-Dombois and Ellenberg (1974). The recorded data was analyzed through CANOCCO and PC-ORD softwares (Haq et al., 2015).

\section{Results}

Forest being important part of ecosystem of KPK and provides a major part of livelihood for indigenous and rural people. These forest also provide medicines, shelter, fuel resources, fodder and aesthetic values to communities. Reserved forests of Sathan Gali (Mansehra) are first time explored to know impact of edaphic and physiognomic factors on the plants and their communities structure. The study was based on comprehensive and planned field visits in year 2015-16. The analysis of area revealed that many plant species are over exploited and many parts of forests are being deteriorating due to dominant species loss. The study area was divided into 13 stands. The study generated list of 136 species which belonged to 58 families. The dominant family was Asteraceae in the area. The collected ecological data was subjected to multivariate analysis and TWINSPAN which produced following communities as described here below. The research work and its analysis showed that reserved forest of Sathan Gali was under stress and many factors were effecting the plants' communities. The data obtained from 13 stands of Reserved Forest were analyzed by TWINSPAN classification protocol. It divided the obtained results into four different plant communities which were Pinus-Pteris-Sarcococca Community, Cedrus-FragariaPteris Community, Pinus-Cedrus-Vibernum Community and Pinus-DigitariaSarcococca Community (Fig. 3).

\section{Communities' description of Sathan Gali reserved forest}

\section{Pinus-Pteris-Sarcococca (PPS) community}

Pinus wallichiana-Pteris vitata-Sarcococca saligna community was recorded at an elevation of 1900-2100 $\mathrm{m}$ in stands 9 and 10. The co-ordinates range was 34.36413 to $34.36449 \mathrm{~N}$ and 73.19157 to $73.19423 \mathrm{E}$. The steepness of slope was $40-70^{\circ}$ on East aspect. This community consisted of 28 plant species. The dominant plant of this community was Pinus wallichiana with IVI value of 87.88. Pteris vitata and 
Sarcococca salignawere co-dominants with IVI value of 13.57 and 5.25, respectively. Therophytes were dominant by contributing 9 species followed by Geophytes and Nanophanerophytes 5 species by each (Fig. 5). Leaf size spectra was dominant by Nanophyll 10 plant species followed by Microphyll by 9 plant species (Fig. 4).

Soil of this community was sandy clay loam with acidic $\mathrm{pH}$, nitrogen $0.41 \%$, potassium 135ppm, phosphorus 7.9 and electrical conductivity 2.4. Organic matter $(\mathrm{OM})$ was less in this community. This describes that PPS community plant taxa prefer acidic and low OM soils, so these dominant in the stands.

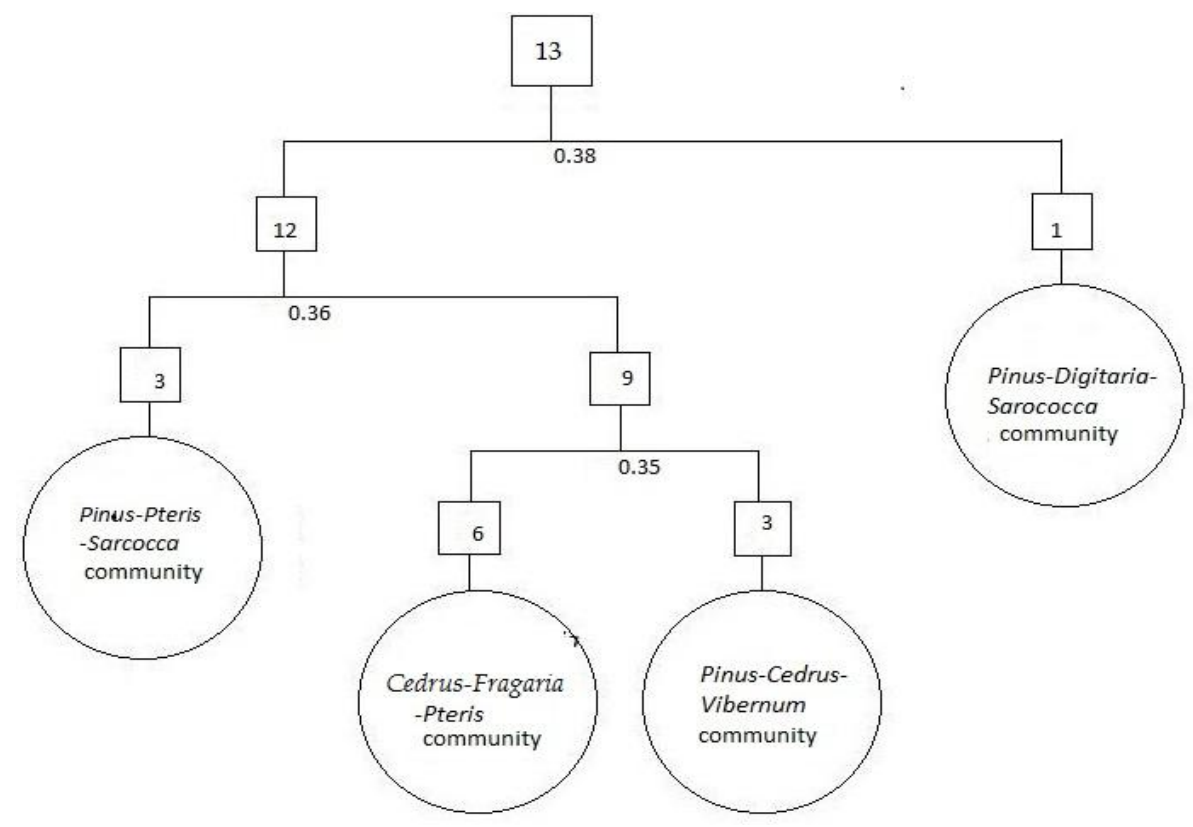

Figure 3. TWINSPAN classification of vegetation of reserved forest

\section{Cedrus-Fragaria-Pteris (CFP) community}

Cedrus deodara-Fragaria nubicola-Pteris vitata community was reported at an elevation of 6400 to $7300 \mathrm{ft}$ in stand $1,3,4,8,12$ and 13. These stands were located at West, North and South aspects. The co-ordinates range was between 34.36132 to $34.36650 \mathrm{~N}$ and 073.12206 to $073,12488 \mathrm{E}$ with $40-65^{\circ}$ steepness of slope. It was dominated by Cedrus deodora with IVI value of 166.05. Fragaria nubicola and Pteris vatata were co-dominant with IVI of 46.38 and 29.28, respectively. A total of 62 plant species in this community were recorded. Among biological spectrum (BS) Geophytes were dominant by contributing 16 plant species followed by Therophytes 14 species, Hemicyptophytes 12 plant species (Fig. 5). A leaf size spectrum was dominant by Microphyll with 23 species followed by Mesophyll 17 and Nanophanerophytes by 7 species (Fig. 4).

Soil of this community was sandy loam with acidic $\mathrm{pH}$, percentage of organic matter was high, and contents of nitrogen, potassium and phosphorous were between in ranges of $0.03-1.3 \%, 105-135 \mathrm{ppm}$ and 5-8, respectively. The electrical conductivity was $0.01-$ 1.2. It shows that CFP community was more dominant in soils of sandy-loamy with high OM range. This makes differ from above PPS community. 


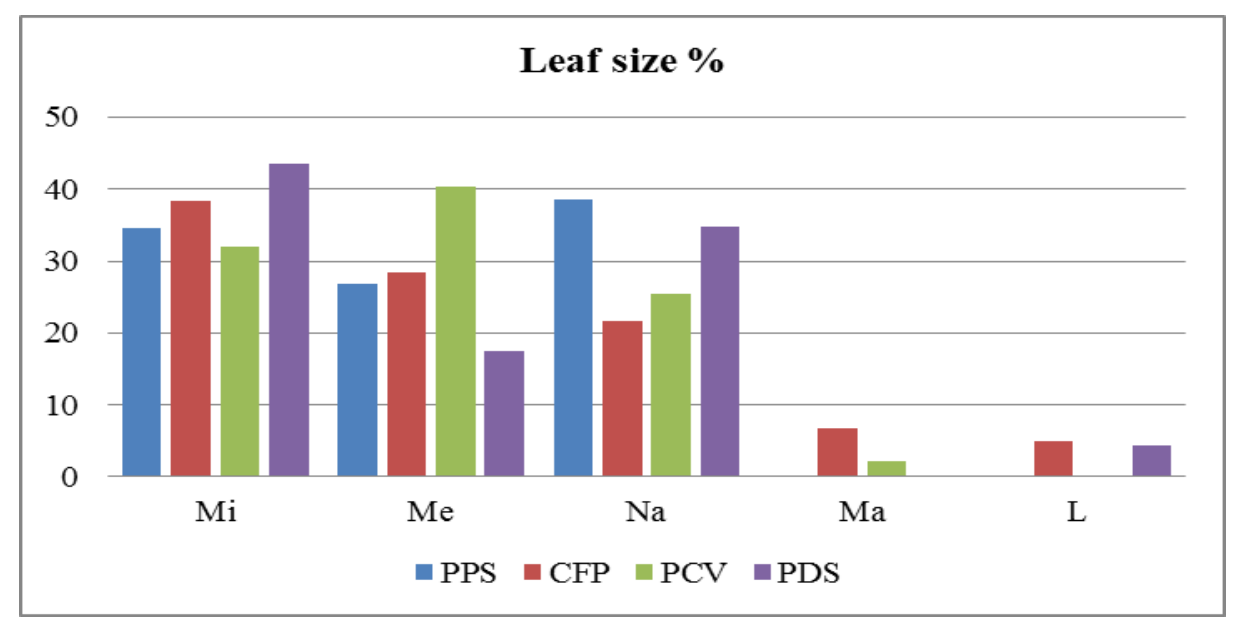

Figure 4. Leaf size of reserved forest plant communities

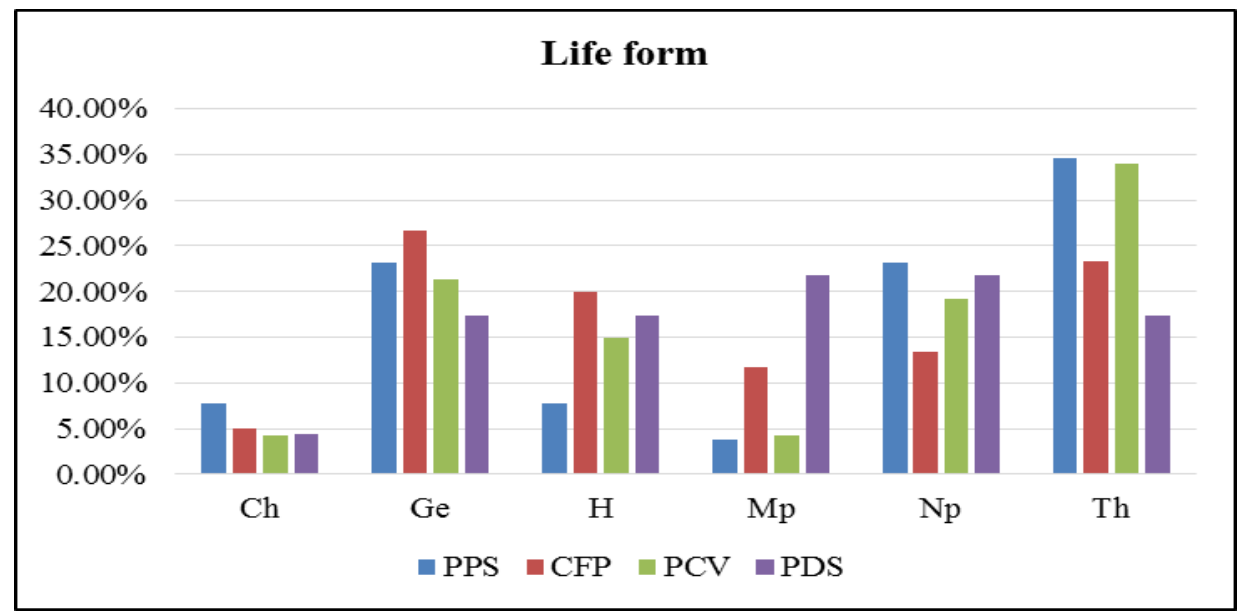

Figure 5. Life form of reserved forest plant communities

\section{Pinus-Cedrus-Viburnum (PCV) community}

At an elevation of 6300-6900 ft Pinus wallichiana-Cedrus deodara-Viburnum cotonifolium community was harbored at Northern aspect with $50-60^{\circ}$ slope of steepness. The co-ordinates range was 34.36432 to $34.36582 \mathrm{~N}$ and 073.11067 to 073. 11741E. Pinus wallichiana was dominant with importance value index of 101.74. Cedrus deodara and Viburnum was co-dominant species with IVI of 29 and 14.94, respectively. A total of 51 plant species were recorded in this community. Therophytes were dominant life form of the vegetation with addition of 16 plant species followed by Geophytes and Nanophanerophytes (Fig. 5). Among leaf size Mesophylls were dominant by contributing 19 species followed by Microphylls 15 plant species (Fig. 4).

Soil of this community was found sandy-clay-loam. The loam soil of this community had acidic $\mathrm{pH}$, less organic matter, potassium, phosphorus and nitrogen were 120-130 ppm, 4-8 and $0.21-0.57 \%$, respectively. The electrical conductivity was $0.01-1.1$. This analysis of community soil and plants types depicts that loamy soil with less OM contents having $\mathrm{N}$ contents of 120-130 ppm prefer to support plants of genera Pinus, Cedrus and Viburnum. So the community PCV is dominating in this belt of forest. 


\section{Pinus-Digitaria-Sarcococca (PDS) community}

At an elevation of $3700 \mathrm{ft}$ in stand 11, Pinus wallichiana- Digitaria nodosaSarcoccoca saligna community was reported. The range of co-ordinates for this community was $34.36132 \mathrm{~N}$ and $73.11791 \mathrm{E}$. This community was recorded at Southern aspect at $50^{\circ}$ slope of steepness. The total numbers of plant species recorded for this community were 24. Pinus wallichiana was dominant with IVI 44.96. Digitaria nodosa and Sarcococca saligna were co-dominant with IVI value of 10 and 6, respectively. Biological spectrum was dominated by Nanophanerophytes having 5 species followed by Hemicyptophytes and Geophytes by 5 plant species each (Fig. 5). A leaf size spectrum was dominant by Microphyll with 10 plant species followed by 5 species of Nanophanerophytes (Figs. 4 and 6).

Soil in this community was sandy loam with high acidic $\mathrm{pH} 7.5$, organic matter percentage was low. The contents of nitrogen, potassium, phosphorous were $0.052 \%$, $125 \% \mathrm{ppm}$, and 3.2 respectively. The electrical conductivity was 1.4. The soil composition and elevation determines the constitution of plants in PDS community. These plants would like to climate of low OM and acidic soil.

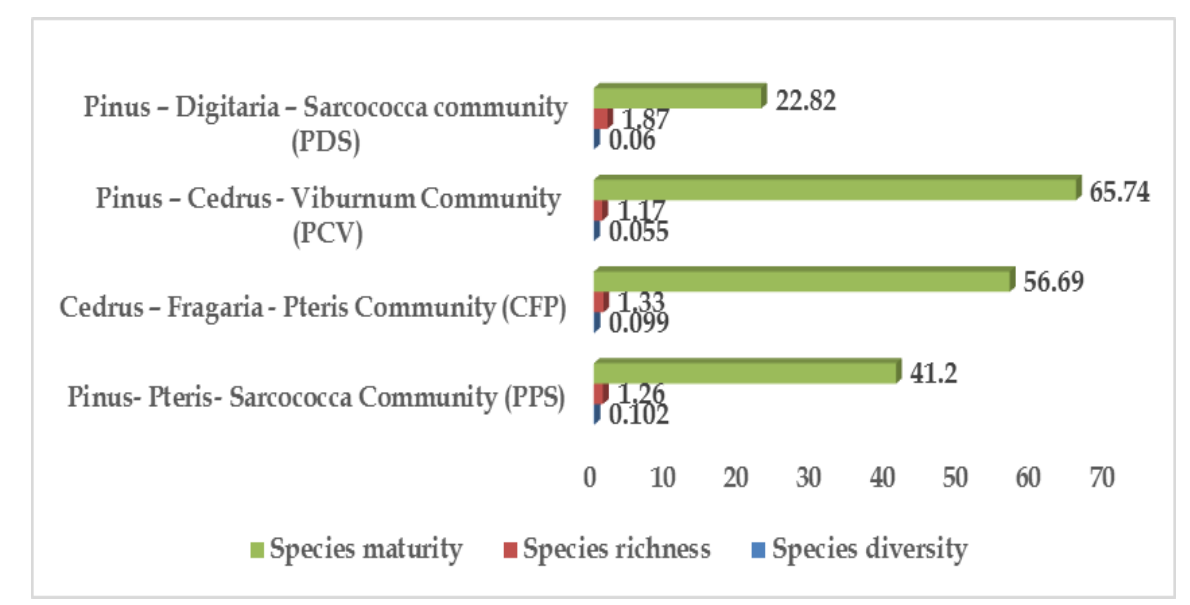

Figure 6. Graphical representation of different components of plant species diversity

\section{Detrended correspondence analysis (DCA)}

The total species surveyed were 136 belonging to 58 families. These data of Reserved Forest's species were subjected to Detrended Correspondence Analysis which indicated that total variation was 3.28. The response data was compositional having a gradient length of $3.3 \mathrm{SD}$ unit long. The DCA ordination showed that the maximum gradient length was 3.32 for axis 1 and 2.57 for axis II. The maximum Eigenvalue was 0.49 for axis 1 and 0.34 for axis II.

The DCA ordination of the species showed that different species clustered in ordination space on the basis of similarities in habitat and species composition. The species clusters including Vaccaria sp, Rhamnus virgata, Ajuga sp., Taxus wallichiana were positively correlated with each other. These species were negatively correlated with Viola sp, Bupleurum lanceolatum, Ajuga bracteosa, Rumex nepalnsis and Isodon rugosus. The species which were positively correlated with each other and negatively correlated with the above species were Juglans regia, Pinus roxburghii, Alnus nitida and Viburnum cotinifolium. The species which were on the top of ordination space 


$$
\text { - } 1093 \text { - }
$$

included Rumex dentatus, Clinopodium vulgare, Indigofera heterantha, Solanum surattense and Saromatum venosum. The species which were near average position included Paeonia emodi, Fragaria nubicola. Myrsine africana and Impatiens bicolor were positively correlated with each other.

DCA ordination of stand also showed that stand of different communities clustered in ordination space almost similar fashion. It was found that Pinus-DigitariaSarcococca community showed different behavior and was away from other communities on axis I. This community distance occurrence is also confirmed by TWINSPAN classification (Figs. 7 and 8). The other communities like Pinus-PterisSarcococca Community was at the top of ordination space while remaining PinusCedrus-Vibernum Community and Cedrus-Fragaria-Pteris Community were in the center (Fig. 8).

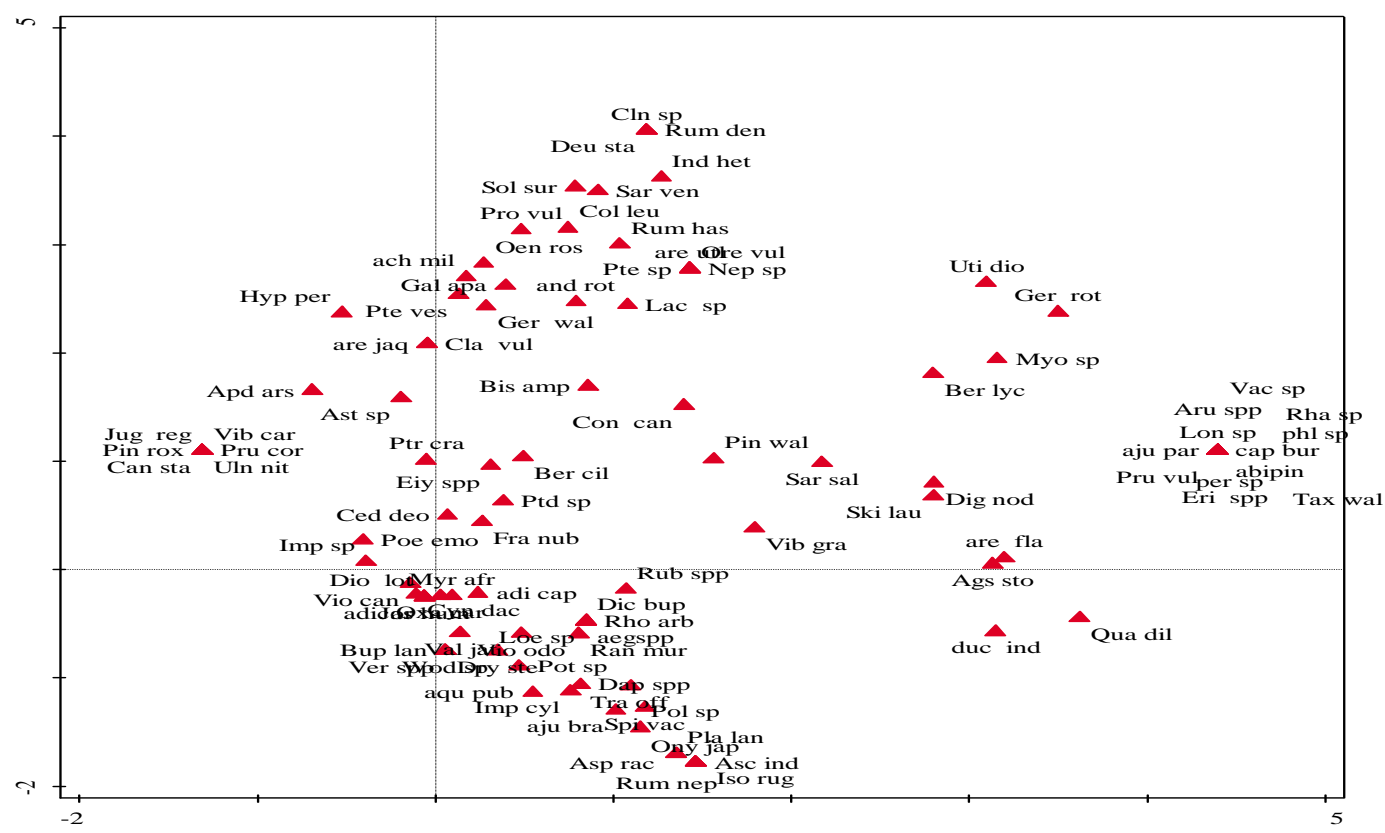

Figure 7. DCA ordination of plant species of reserved forest

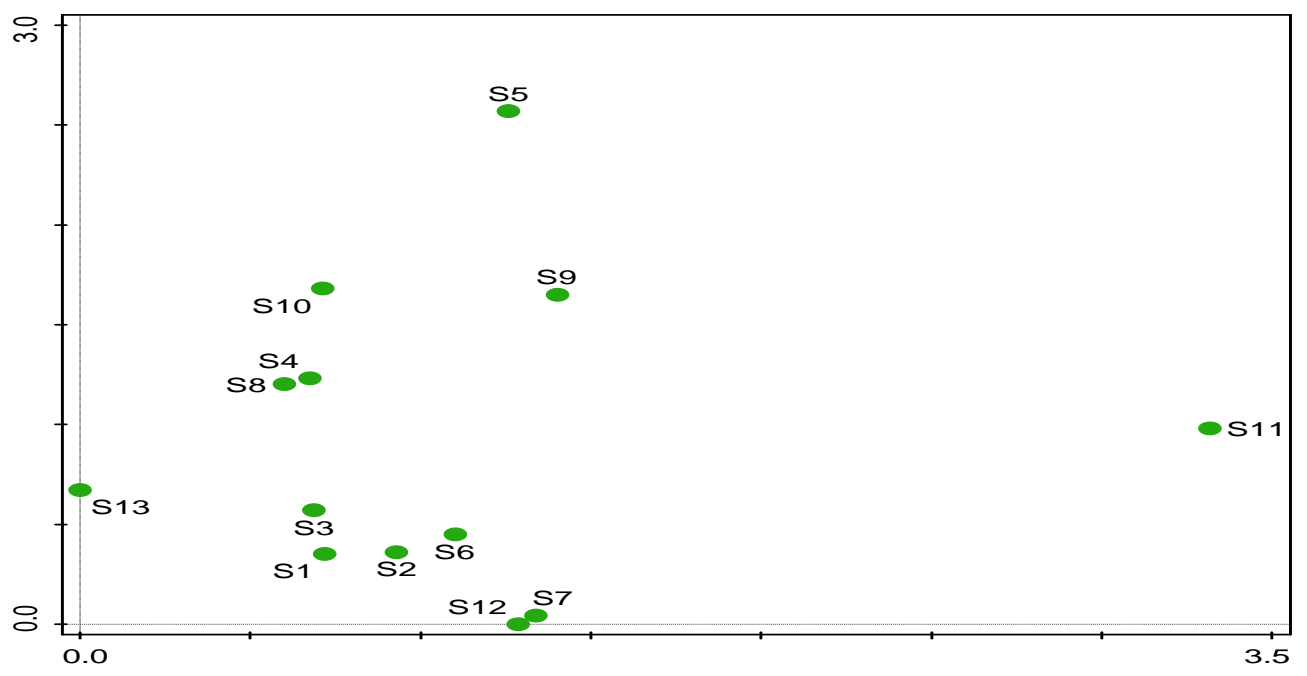

Figure 8. DCA ordination of stands of vegetation of reserved forest 


\section{Canonical correspondence analysis (CCA)}

The collected data of reserved forest of Sathan Gali was further analyzed by using other statistical method named Canonical Correspondence Analysis. CCA ordination showed that total variation was 3.28, explanatory variable account for $100 \%$ while adjusted explained variation was $0 \%$. The maximum eigenvalue was 0.49 for axis 1 and 0.40 for axis II. The explained variation for axis I was 14.88 and 27.32 for axis II. The pseudo canonical correlation for all axis was 1 and occurrence value was 274 . The permutation test result showed that pseudo $\mathrm{F}$ less than 0.1 and $\mathrm{P}=1$. The CCA ordination of species showed that different species were sensitive with environmental variable and clustered in ordination space at different locations.

\section{Impact of edaphic factors on plant communities' structure}

The species which were sensitive with altitude, air moisture, aspect, wind pressure and potassium were Arisaema flavum, Quercus dilatata, Duchesnea indica, Aegopodium burttii, Taxus wallichiana, Abies pindrow. Geranium rotundifolium. Urtica diocca and Sarcococca saligna taxa were positively correlated with electrical conductivity (EC) of soil. Some species were positively correlated with nitrogen conc., longitude, latitude and organic matter which inclided Paeonia emodi, Hypericum perforatum, Viburnum grandiflorum, Juglans regia. The taxa Pteris sp. and Geranium wallichinum were positively correlated with phosphorus contents and its availability to the plants.

\section{Impact of climatic factors on plant communities' structure}

The species which were highly sensitive to temperature were Solanum surratense, Saromatum venosum, Indigofera hetrentha and Rumex hastatus. The CCA ordination of environmental variables showed that the altitude and aspects were negatively correlated with temperature, slope, angle and phosphorus (Fig. 10). Similarly nitrogen, latitude and organic matter were negatively correlated with electrical conductivity and $\mathrm{pH}$. The maximum gradient strength was recorded for $\mathrm{pH}$, aspect, nitrogen and latitude. The minimum strength was recorded for potassium followed by slope angle and air moisture. The maximum stands of communities were near average position while Pinus-Digitaria-Sarcococca Community was away from average position contributing 25 species (Fig. 9), which showed that this community was rich in floristic composition and habitat type from rest of the associations (Fig. 10).

The results depict that edaphic and environmental factors are key constraints on forest plant composition and their proliferation in an area. Various climatic and soil composition do impose impact on types of dominant taxa in the study area of reserved forest of Sathan Gali in Mansehra of KPK. The characteristics of plants communities of different locations were presented in Figure 6 and it depicts the structure, richness, diversity and maturity of analyzed strands.

\section{Discussion}

\section{Geographic analysis of study area}

Pakistan being the part of western Himalaya harbors rich floral diversity owing to important geographical position. The study area (reserved forest of Sathan Gali) lies in 


$$
\text { - } 1095 \text { - }
$$

the western Himalayas shows rich floristic diversity. A total of 127 plants species belonging to 58 families were recorded from Reserved forest of Sathan Gali. According to plant habit, herbaceous growth form with $73.64 \%$ species was the most dominant one. Our findings are in congruent with previous works of many researchers conducted in allied and neighboring regions of the country (Ijaz, 2014; 2015; Khattak et al., 2015; Khan et al., 2015a, b; Shah et al., 2015; Ahmad et al., 2016; Rahman et al., 2016a, b).

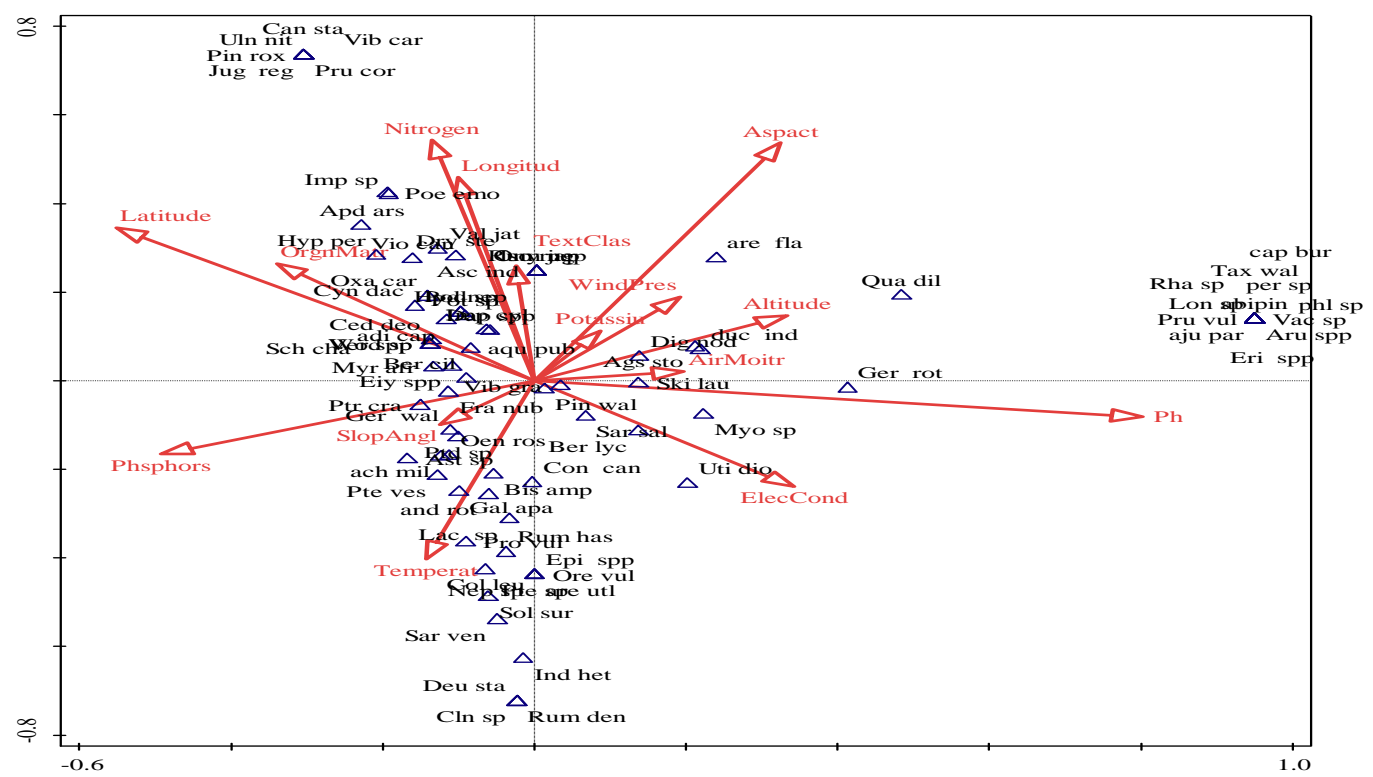

Figure 9. CCA ordination of plant species of reserved forest

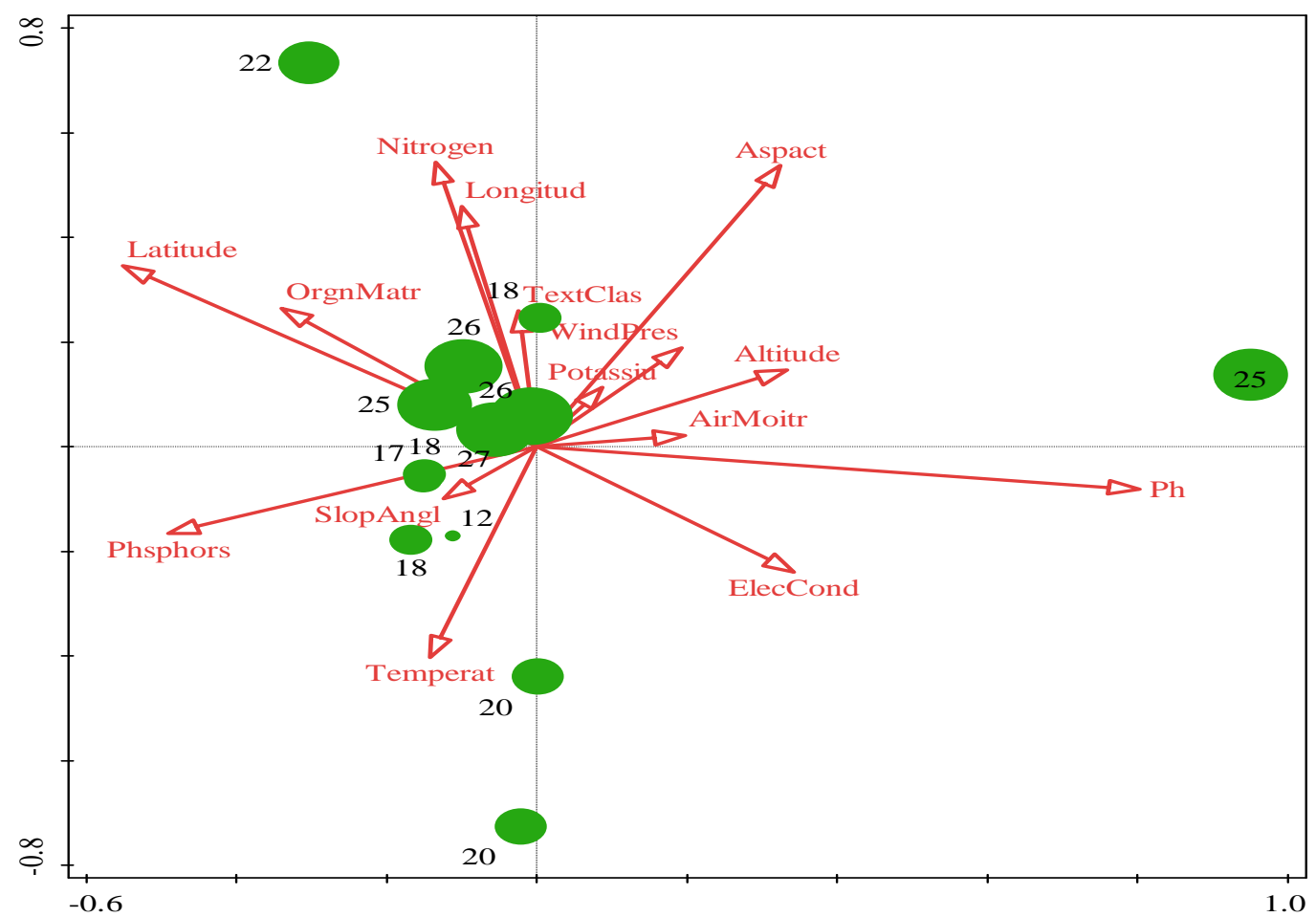

Figure. 10. CCA ordination of stands of reserved forest 


\section{Phytosociological analysis}

Phytosociology is the study of plant communities and their inter-relationship and interaction with environment. While a community is grouping of plant population formed in one habitat type in specific area, display mutual competition and dependence. The existence and establishment of plant communities indicates the plant type and habitat condition under which they develop (Malik, 1986). The analysis of the study area showed that dominant family was found to be Asteraceae followed by Labiateae (10 species), Poaceae and Rosaceae (8 plant species) each, Polygonaceae and Pteridaceae by 5 species each. The past work of Stewart (1972) depicted that these families are dominantly occurring in Pakistan and Azad Jammu and Kashmir. The work of other ecologists described that Himalayan and other areas like Sathan Gali forest do had more or less same list of families as we had listed in the research (Iqbal et al., 2015; Ijaz et al., 2016).

There is natural principle that edaphic and physiognomic parameters do exert their pivotal impacts on type of plants in an area, their correlation with other plants-making communities. In the field analysis of Sathan Gali forest, it was found that key types of four communities were found. Their composition was variable with factors of environmental such as altitude, latitude, temperature, precipitation, humidity and soil type. Similar ideas were described by Berg et al. (2000) and he said that precipitation and elevation strongly influence the floristic composition among different forests of an area. The floristic diversity, richness and maturity are also correlated with variation in altitude (Shaheen et al., 2016; Adam and Mamat, 2005). The life span of plants and their intercorrelation do become changed with alteration in edaphic factors and time elapsed and similar findings were reported by Madsen and Ilgaard in 2008 \& Titshall et al., 2000.

\section{Community analysis in study area by TWINSPAN}

This research produced list of 131 plants species belonging to 58 families from the study area. The data collected from 13 stands of 455 quadrats resulted in a total of 4 different plant communities recognized by TWINSPAN viz (1) Pinus-PterisSarcococca Community (PPS); (2) Cedrus-Fragaria-Pteris Community (CFP); (3) Pinus-Cedrus-Viburnum Community (PCV) and (4) Pinus-Digitaria-Sarcococca Community (PDS). These communities' occurrence and congruence was interdependent on altitude, precipitation, latitude, soil structure, minerals contents in soil as shown in the results section above. Similar studies were conducted by Haq on subtropical forests of Nandiar Khuwar catchment district Battagram, Khyber Pakhtunkhwa, Pakistan and he found edaphic and climatic factors had strong influence on types of communities and their richness (Haq et al., 2015).

\section{Community analysis in study area by $D C A \& C C A$}

In constrained DCA ordination of reserved forest of Sathan Gali indicated that the total variation in the species data was 3.28. The DCA ordination of the species showed that different species clustered in ordination space on the basis of similarities in habitat and species composition. CCA showed percentage variance of $10.16 \%, 15.98 \%$ and $21.01 \%$ for axis I, II and III, respectively. This result showed that there is strong association of species and habitat types with environmental variables. CCA technique is used to find out the relationship between environmental variable and vegetation. This 
CCA analysis has also been used to determine the vegetation-environmental relationship (Mehmood et al., 2015). It is therefore important to correlate the vegetation structure of the area with environmental variables for a proper understanding of the of plant species distribution mechanism in an area (Eriksson and Bergstrom, 2005). The first two axis explain $45 \%$ of total variation so our analysis indicate significant results. The length of arrow showed the magnitude of particular factor's effect on plant species distribution.

Mehmood et al. (2015) and Haq et al. (2015) reported that the distribution of plant is greatly affected by variation in altitude in the areas adjacent to study field. Zhang et al. (2006) also showed that altitude is an important factor for plant distribution. Due to change in altitude the temperature declines and humidity increases which favors the plant of higher elevation. Our findings are also in accordance with Shaheen et al. (2011) who reported that altitude is a main parameter for distribution of species in Bagh, AJK. These results showed that a specific environmental variable has a great impact on species distribution in different vegetation zones of the study area (Haq et al., 2015).

The life form of plants is an adaptive response to environment and provides an ecological classification that may be indicative of habitat conditions (Archibold, 1995). Occurrence of similar biological spectrum in different regions indicates similar climatic conditions. The present findings as described in the result section were in agreement with Shaheen et al. (2016), who had reported Therophytes as the leading life form in Havelian, Abbottabad, Pakistan.

Leaf spectra (LS) are characteristic of the existing environmental and habitat conditions of any area and our classes on basis of LS are also in-line with past work of Hussain et al. (2015). Leaf size spectrum (LSS) analysis showed that the study area was dominated by microphylls contributing 68 (40.47\%) species, followed by Mesophylls containing $45(26.78 \%)$ species and these types of classes were also mentioned by Malik et al. (2007) where he found that microphyllous and nanophyllous were the dominant leaf size from Kotli Azad Kashmir and Waziristan and these clustering was totally based edaphic and climatic factors (Siddiqui et al., 2014). So, on basis this research findings, indigenous people of the Sathan Gali and relevant departments can use this research information for propagation of the most prevalent species of the plants as this area's soil and climate will prefer to assist such taxa to grow and compete with already plants' communities. These forests can be made rich and diverse by using the preservation and conservation strategies implemented after due re-forestation process.

\section{Conclusion}

It is concluded that phytosociological analysis of any area is the best method to find the appropriate species for growing or cultivation on it. The findings of the work on Sathan Gali reserved forest showed that Pinus wallichian, Taxus wallichiana, Pinus roxburghii, Alnus nitida Quercus dilatata, Juglans regia, Abies pindrow, Arisaema flavum, Duchesnea indica, Aegopodium burttii, Rumex dentatus, Clinopodium vulgare, Indigofera heterantha, Solanum surattense, Saromatum venosum, Paeonia emodi, Fragaria nubicola. Myrsine Africana, Impatiens bicolorBupleurum lanceolatum, Ajuga bracteosa, Rumex nepalnsis and Isodon rugosus were prominent plants of the area. These are providing key resources as food, fodder, sheltering, hedging, furniture, medicines, aesthetics and commercial purposes i.e. livelihood for the indigenous and neighboring areas of Sathan Gali reserved forest of Mansehra, Pakistan. It was 
concluded that mainly edaphic factors and environmental characteristics are limiting constraints for the forest diversity, richness and maturity. The controlling and modification of these analyzed parameters may assist in rich and gloomed forest growth having dynamic communities' structure.

\section{REFERENCES}

[1] Adam, J. H., Mamat, Z. (2005): Floristic composition and structural composition of lime stone forests at three different elevations in Bau, Kuching and Saravak, Malaysia. - J. Biol. Sci. 5(4): 478-485.

[2] Ahmad, Z., Khan, S. M., Ali, S., Rahman, I. U., Ara, H., Noreen, I., Khan, A. (2016): Indicator species analyses of weed communities of maize crop in district Mardan, Pakistan. - Pak. J. Weed Sci. Res. 22(2): 227-238.

[3] Ali, S. I., Qaisar, M. (1995-2004): Flora of Pakistan. - Pakistan Agriculture Research Council, Islamabad.

[4] Allen, S. E., Grimshaw, H. M., Parkinson, J. A., Quamby, C., Roberts, J. D. (1986): Chemical Analysis. - In: Moore, P. D., Chapman, S. B. (eds.) Methods in Plant Ecology. (2nd ed.). Blackwell Scientific Publications, Oxford.

[5] Archibold, O. W. (1995): Ecology of World Vegetation. - Chapman \& Hall, London.

[6] Berg, V. D., Eduardo, G., Oliveira-Filho, T. A. (2000): Floristic composition and phytosociological structure of a riparian forest in Itutinga, State of Minas Gerais, Brazil and comparisons with other areas. - Rev. Bras. Bot. 23(3): 231-253.

[7] Currie, D. J, Francis, A. P. (2004): Regional versus climate effect on taxon richness in angiosperms; reply to Qian and Ricklefs. - American Naturalist 163: 780-785.

[8] Daubenmire, R. F. (1959): A canopy coverage method of vegetation analysis. - North West Sci. 33: 43-46.

[9] Eriksson B. K., Bergström, L. (2005): Local distribution patterns of macroalgae in relation to environmental variables in the northern Baltic Proper. - Estuar. Coast. Shelf Sci. 62: 109-117.

[10] Fiaz, M. (2012): Species Diversity of Basidiomycetes of District Mansehra. - PhD Thesis, Hazara University Mansehra, KPK, Pakistan.

[11] Haq, F., Ahmad, H., Iqbal, Z. (2015): Vegetation description and phytoclimatic gradients of subtropical forests of Nandiar Khuwar Catchment District Battagram. - Pak. J. Bot. 47(4): 1399-1405.

[12] Hussain, F., Shah, S. M. Badshah, L., Durrani, M. J. (2015): Diversity and ecological characteristics of flora of Mastuj Valley, district Chitral, Hindukush range, Pakistan. Pak. J. Bot. 47(2): 495-510.

[13] Hussain, M. S., Sultana, A., Khan, J. A., Khan, A. (2008): Species composition and community structure of forest stands in Kumaon Himalaya, Uttarakhand, India. Tropical Ecology 49(2): 167-181.

[14] Ijaz, F. (2014): Biodiversity and traditional uses of plants of Sarban Hills, Abbottabad. M. Phil. Thesis, Hazara University Mansehra, KP, Pakistan.

[15] Ijaz, F., Iqbal, Z., Alam, J., Khan, S. M., Afzal, A., Rahman, I. U., Islam, M., Sohail, M. (2015): Ethnomedicinal study upon folk recipes against various human diseases in Sarban Hills, Abbottabad, Pakistan. - World J. Zoology 10(1): 41-46.

[16] Ijaz, F., Iqbal, Z., Rahman, I. U., Khan, A., Shah, S. M., Khan, G. M., Afzal, A. (2016): Investigation of traditional medicinal floral knowledge of Sarban Hills, Abbottabad, KP, Pakistan. - J. Z. 179: 208-233.

[17] Iqbal, M., Khan, S., Khan, M. A., Rahman, I. U., Abbas, Z. (2015): Exploration and inventorying of weeds in wheat crop of the district Malakand, Pakistan. - Pak. J. Weed Sci. Res. 21(3): 435-452. 
[18] Kent, M., Coker, P. (1994): Vegetation Description and Analysis. A Practical Approach. - John Wiley and Sons, Chichester.

[19] Khan, K. U., Shah, M., Ahmad, H., Ashraf, M., Rahman, I. U., Iqbal, Z., Khan, S. M., Majid, A. (2015a): Investigation of traditional veterinary phytomedicines used in Deosai Plateau, Pakistan. - Global Vet. 15(4): 381-388.

[20] Khan, S. M., Din, N. U., Sohail, I. U., Rahman, F., Ijaz, Z., Ali, Z. (2015b): Ethnobotanical study of some medicinal plants of Tehsil Kabal, Distrct Swat, KP, Pakistan. - Med. Aromat. Plants 4(3): 189.

[21] Khattak, N. S., Nouroz, F., Rahman, I. U., Noreen, S. (2015): Ethnoveterinary uses of medicinal plants of district Karak, Pakistan. - Journal of Ethnopharmacol. 171: 273-279.

[22] Leveque, C. M. (2001): Les parcs culturels: presentation dune initiative europeenne. - In: Sagnes, J. (ed.) Deux siecles de Tourisme en France. Presses Universitaires de Perpignan, Perpignan.

[23] Madsen, J. E., Iigaard, I. B. (2008): Floristic composition, structure and dynamics of an upper montane rain forest in Southern Ecuador. - Nordic J. Bot. 14(4): 403-423.

[24] Malik, N. Z., Arshad, M., Mirza, N. S. (2007): Phytosociological Attributes of Different Plant Communities of Pir Chinasi Hills of Azad Jammu and Kashmir. - International Journal of Agriculture \& Biology 9(4): 569-574.

[25] Malik, Z. H. (1986): Phytosociological study on the vegetation of Kotli Hills. - M. Phil Thesis, University of Peshawar.

[26] McGrady-Steed, J., Morin, P. J. (2000): Biodiversity, density compensation and the dynamics of populations and functional groups. - Ecology 81: 361-373.

[27] Mehmood, A., Khan, S. M., Shah, A. H., Ahmad, H. (2015): First floristic exploration of the District Torghar, Khyber Pakhtunkhwa, Pakistan. - Pak. J. Bot. 47(SI): 57-70.

[28] Mueller-Dombois, D., Ellenberg, H. (1974): Aims and Methods of Vegetation Ecology. Wiley and Sons, New York.

[29] Nasir, E., Ali, S. I. (1971-1994): Flora of Pakistan. - Pakistan Agriculture Research Council, Islamabad.

[30] Niemi. G. J., Donald, M. E. (2004): Application of ecological indicators. - Annual Review of Ecology, Evolution and Systematics 35(57): 89-111.

[31] Peer, T., Gruber, J. P., Millingard, A., Hussain, F. (2007): Phytosociology, structure and diversity of the steppes vegetation in the mountains of Northern Pakistan. Phytocoenologia 37: 1-65.

[32] Rahman, I. U., Ijaz, F., Afzal, A., Iqbal, Z., Ali, N., Khan, S. M. (2016a): Contributions to the phytotherapies of digestive disorders. Traditional knowledge and cultural drivers of Manoor Valley, Northern Pakistan. - J. Ethnopharmacol. 192: 30-52.

[33] Rahman, I. U., Ijaz, F., Afzal, A., Iqbal, Z., Ali, N., Afzal, M., Khan, M. A., Muhammad, S., Qadir, G., Asif, M. (2016b): A novel survey of the ethno medicinal knowledge of dental problems in Manoor Valley (Northern Himalaya). - Pakistan. J. Ethnopharmacol. 194: 877-894. DOI: http://dx.doi.org/10.1016/j.jep.2016.10.068.

[34] Raunkiaer, C. (1934): The Life Forms of Plants and Statistical Plant Geography. - Oxford University Press, London.

[35] Rieley, J., Page, S. (1990): Ecology of Plant Communities: A phytosociological Account of the British Vegetation. - John Wiley and Sons, Inc., New York.

[36] Rodolfo, E., Pichi, S. (1948): An index for establishing the degree of maturity in plant communities. - Journal of Ecology 36(1): 85-90.

[37] Shah, A. H., Khan, S. M., Shah, A. H., Mehmood, A., Rahman, I. U., Ahmad, H. (2015): Cultural uses of plants among Basikhel Tribe of District Tor Ghar, Khyber Pakhtunkhwa, Pakistan. - Pak. J. Bot. 47(SI): 23-41.

[38] Shaheen, H., Shinwari, Z. K. (2012): Phytodiversity and endemic richness of Karambar lake vegetation from Chitral, Hindukush-Himalayas. - Pak. J. Bot. 44(1): 15-20. 


$$
\text { - } 1100 \text { - }
$$

[39] Shaheen, H., Qureshi, R. A., Shinwari, Z. K. (2011): Structural diversity, vegetation dynamics and anthropogenic impact on lesser Himalayan subtropical forests of Bagh District, Kashmir. - Pak. J. Bot. 43(4): 1861-1866.

[40] Shaheen, S., Iqbal, Z., Ijaz, F., Alam, J., Rahman, I. U. (2016): Floristic composition, biological spectrum and phenology of Tehsil Havelian, District Abbottabad, Pakistan. Pak. J. Bot. 48(5): 1849-1859.

[41] Siddiqui, M. F., Shaukat, S. S., Ahmed, M., Khan, I. A., Khan, N. (2014): Foliar and soil nutrient distribution in conifer dominated forests of moist temperate areas of Himalayan and Hindukush region of Pakistan: a multivariate approach. - Pak. J. Bot. 46(5): 18111827.

[42] Titshall, L. W., O'Connor, T. G., Morris, C. D. (2000): Effect of long-term exclusion of fire and herbivory on the soils and vegetation of sour grassland. - African Journal of Range and Forage Science 17: 70-80.

[43] Whittaker, R. H. (1977): Evolution of species diversity in land plant communities. Evolutionary Biology 10: 1-67.

[44] Zhang, X. P., Wang, M. B., Shi, B. (2006): Quantitative classification and ordination of forest communities in Pangquangou National Nature Reserve. - Acta Ecologica Sin. 26(3): 754-761. 